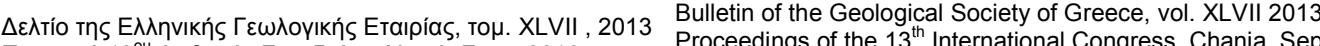

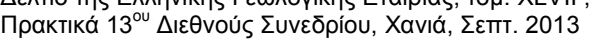
2013

\title{
ENGINEERING GEOLOGICAL CONDITIONS OF KLOKOVA MOUNTAIN, GREECE
}

\author{
Saroglou H. ${ }^{1}$ and Kazilis N. $^{2}$ \\ ${ }^{I}$ National Technical University of Athens, School of Civil Engineering, Department of \\ Geotechnics,saroglou@central.ntua.gr \\ ${ }^{2}$ Geodata Greece, Theodorou Litsa Str. 9, 115 27, Thessaloniki
}

\begin{abstract}
The paper presents the engineering geological conditions of Klokova Mountain and discusses the problems, which relate with the presence of fault structures, karst features and steep rock slopes in relation to the existing and planned motorway. The engineering geological setting of the limestone formations is characterized by the development of karst and the fault presence.

The karst pattern and an interpretation of the fault geometry of the area are presented based on geological mapping. Additionally, rockmass conditions are presented based on field data and borehole findings. The geotechnical conditions have been assessed by geotechnical investigations, which were executed for the design of the new highway.

Finally, a risk assessment of the area due to rockfalls is presented, considering that the risk level is very high due to the presence of very steep and fractured slopes, formed partially parallel to fault surfaces, and the high seismicity of the broader area. Rockfall episodes are prone to occur under seismic loading during a strong earthquake in the area but also due to high rainfall incidents.
\end{abstract}

Key words: Karst, Limestone, Fault, Rockfall.

\section{Пєрí $\eta \psi \eta$}

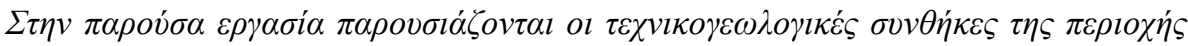

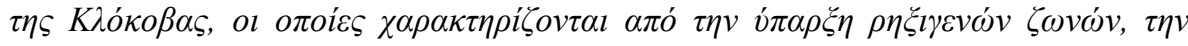

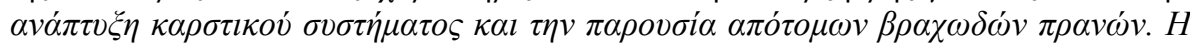

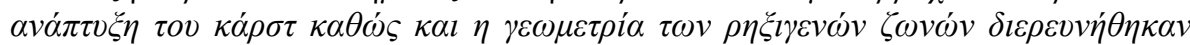

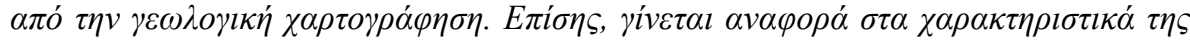

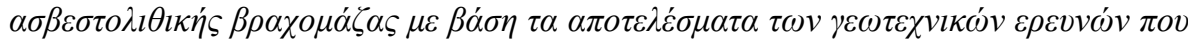

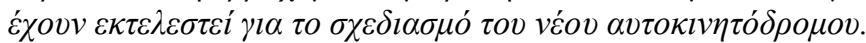

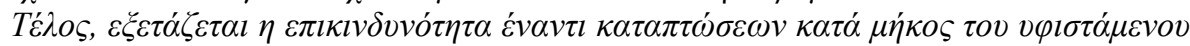

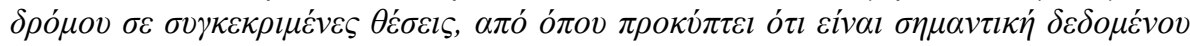

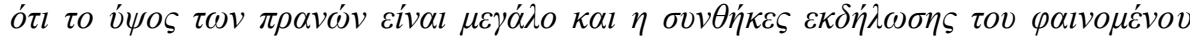

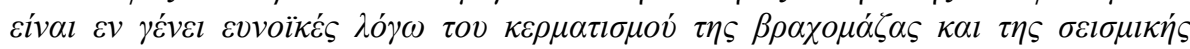

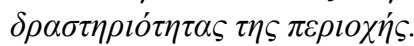

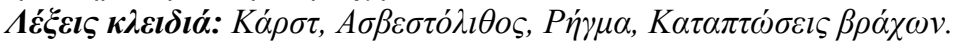

$\underline{\text { XLVII, No } 3-1872}$ 


\section{Introduction}

The mountain range of Klokova has a NNW direction, with maximum altitude of $1050 \mathrm{~m}$ and is surrounded by zones of milder morphology. The mountain in the south ends in the north coastline of Patraikos gulf, which is characterized by steep slopes (mean angle of $50^{\circ}$ and at some places up to $75^{\circ}$ ), while their slope foot is covered by lateral slope scree material with varying degree of cementation. The steep morphology of Klokova slopes is formed due to fault surfaces, which intersect or align parallel to the National roadway. The new highway in the area of Klokova mountain is planned to be constructed either with bridges or twin tunnels. The alignment of the civil engineering works is not shown in the present paper since it has not been finalized.

\section{Geological Setting}

\subsection{Geological Formations}

The geological formations encountered in Klokova area are: a) loose slope talus, b) limestone scree with varying degree of cementation and c) limestones. Klokova mountain is forms an anticline (Aubouin et. al., 1958).

\section{Loose slope talus}

The formation of the talus is recent slope scree, which due to their placement on the steep limestone slopes has an extremely loose and metastable nature. It is in a state of periodical downward movement on the slopes. Due to their meta-stable condition, these periodical movements may trigger with only small scale mechanisms, such as a temporary wetting (or maybe saturation) of the material during a heavy rainfall, a relatively weak seismic loading or foot erosion of the talus slope due to natural or man made causes (excavation of slopes). Concerning the thickness of the talus formation the maximum thickness encountered in the boreholes performed in the area was $16 \mathrm{~m}$.

\section{Limestone scree slightly to moderately cemented.}

They are characterized by a varying degree of cementation, while their bedding is well developed. At some places clay layers are encountered in the formation. They consist of gravel, pebbles and limestone fragments, with dimensions up to $10 \mathrm{~cm}$, cemented with silty-sandy but also calcitic materials. In some places, the cementing material is clayey. Generally, the cementation degree depends on the nature of the cementing material and the age of the individual layers in the formation.

\section{Limestone scree moderately to highly cemented.}

The moderately to highly cemented scree is characterized by high cohesion, which originates from the secondary high degree of their cementation. The degree of cohesion depends highly on the type of cementing material. Additionally, they have rock-like behaviour thus a high friction angle since they are found stable in the existing highway slopes. It was formed by the cementation of the limestone scree, following chemical procedures with cementing matrix that is mainly of calcareous origin. The formation is karstified and the karst is developed along the bedding planes with dimensions between a few centimeters up to 1-2 meters and in the form of gullies when related to faults.

Eocene limestones, encountered in the east part of Klokova mountain.

It is characterized as moderately bedded with very good interlocking of the rock blocks. The rock blocks are cubic, formed by three main joint sets. The discontinuity surfaces are moderately rough to rough, slightly to moderately weathered, with clay or travertine infillings or empty. The bedding planes of the limestone are pervasive. The limestone is slightly karstified. The development of karst is only along bedding planes leading to their widening up to $30-40 \mathrm{~cm}$.

$\underline{\text { XLVII, No } 3-1873}$ 
Cretaceous limestones, encountered in the central and west part of Klokova mountain.

The mountain is primarily formed by the Cretaceous limestones. They are usually slightly to moderately fractured, with cubical blocks formed by three orthogonal discontinuity sets, which result to a blocky rockmass with good behaviour. In some locations, they are moderately to heavily fractured due to the presence of more than three discontinuity sets, which form a very blocky rockmass with generally small blocks. In this case the interlocking of rock pieces remains very good. In both rock types encountered, the discontinuity surfaces are rough, slightly to moderately weathered, generally open, with or without hard calcitic infilling material.

Additionally, broken zones exist in some places due to the presence of faults, which generally have a width of a few meters. In these zones, the rockmass is characterized by a tight structure and thus the interlocking of the rock particles is good. The limestone is characterized as moderately karstified with fracture karst (developed along faults with opening of a few centimeters up to 2-3 $\mathrm{m})$ and sometimes along discontinuity planes.
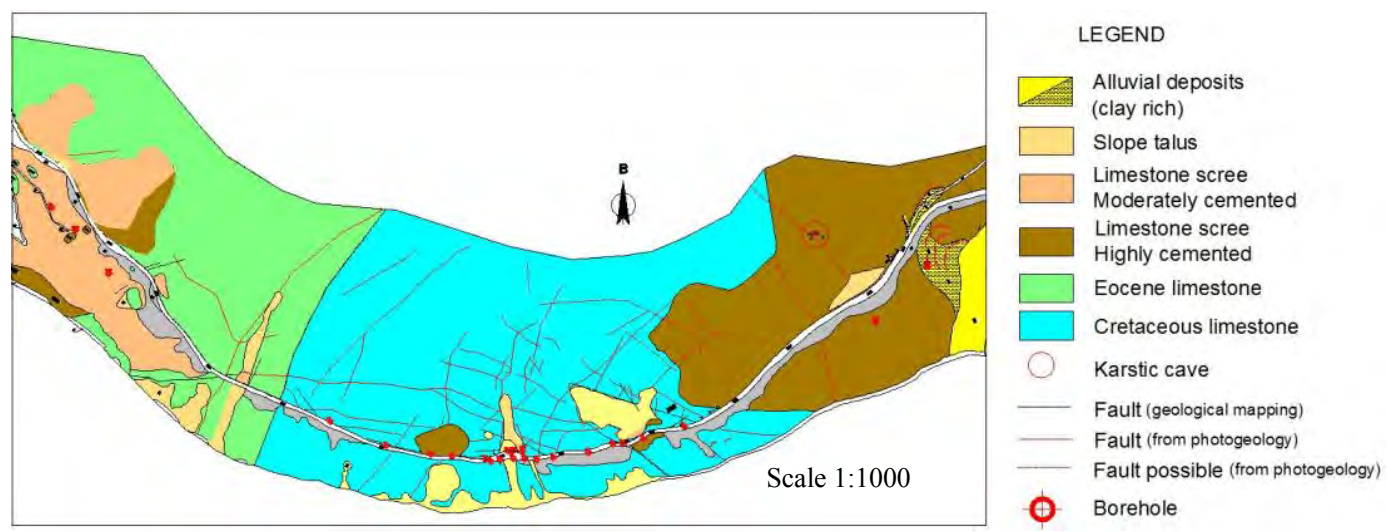

Figure 1 - Geological map of Klokova area.

\subsection{Tectonic Setting}

The most important tectonic structures of the broader area are interconnected with tectonic lines with ENE-WSW direction, parallel to which major discontinuities are developed that sometimes are very wide with openings in the range of tenths of centimeters up to a meter.

Furthermore, fault surfaces are encountered, with a general NE-SW and WNW-ESE trend, parallel to which some sets of minor discontinuities form.

\section{Karst Development - Fault structure}

\subsection{Karst}

The importance of determining the karstic network pattern and the anticipated groundwater flow in such carbonate rocks when tunneling is very crucial in order to forecast and confront related problems (Marinos P., 2005). The geological formations that are characterized by karstic voids in Klokova area were: a) the highly cemented limestone scree, b) The Cretaceous limestones and c) the Eocene limestones. The karst types were evaluated based primarily on geological mapping (Geodata, 2009) and compared with the borehole findings (from Nama S.A. - Kastor Ltd, 2005 and General Consulting Ltd - Istria, 2007).

Two types of karstic voids were found in the formation of the highly cemented limestone scree:

- Those developed along the bedding planes, with generally small dimensions up to $1 \mathrm{~m}$ 
- Gullies developed along faults with dimensions up to $5 \mathrm{~m}$ (Figure $2 \mathrm{a}$ and $\mathrm{b}$ ). The location of such a karstic void is shown in Figure 1, coinciding with a fault line.

Two types of karstic features were encountered in the Cretaceous limestones:

- Fracture karst, which is developed along fault planes with dimensions ranging from a few centimeters up to 2-3 meters.

- More rarely, fracture karst, developed along discontinuity planes, is encountered, which has dimensions less than one meter.

The development of karst in the Eocene limestone is encountered only along bedding planes, thus the width of the voids is up to $0.5 \mathrm{~m}$.
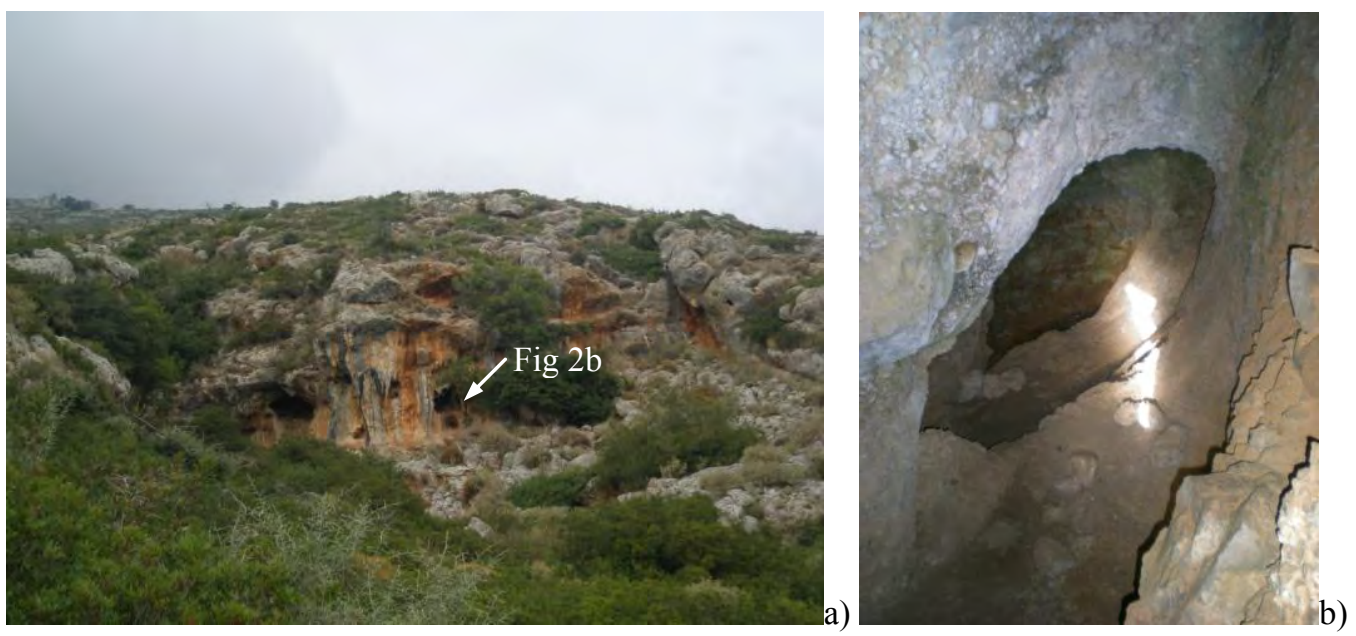

Figure 2 - Karstic voids related to faults in cemented scree a) general view, b) detail of void.

The dimensions of the voids in the cemented scree formation, as encountered in boreholes, range between 0 and $1.0 \mathrm{~m}$ mainly depicting karst developed along bedding planes (Figure 3a). Both karst types of the limestone formation were found in the boreholes. More specifically, karst developed along discontinuities with dimensions less than $1.0 \mathrm{~m}$ was commonly encountered (Figure $3 \mathrm{~b}$ ) as well as one case of an empty void with dimensions equal to $3.2 \mathrm{~m}$ reflecting the connection with fault structure.
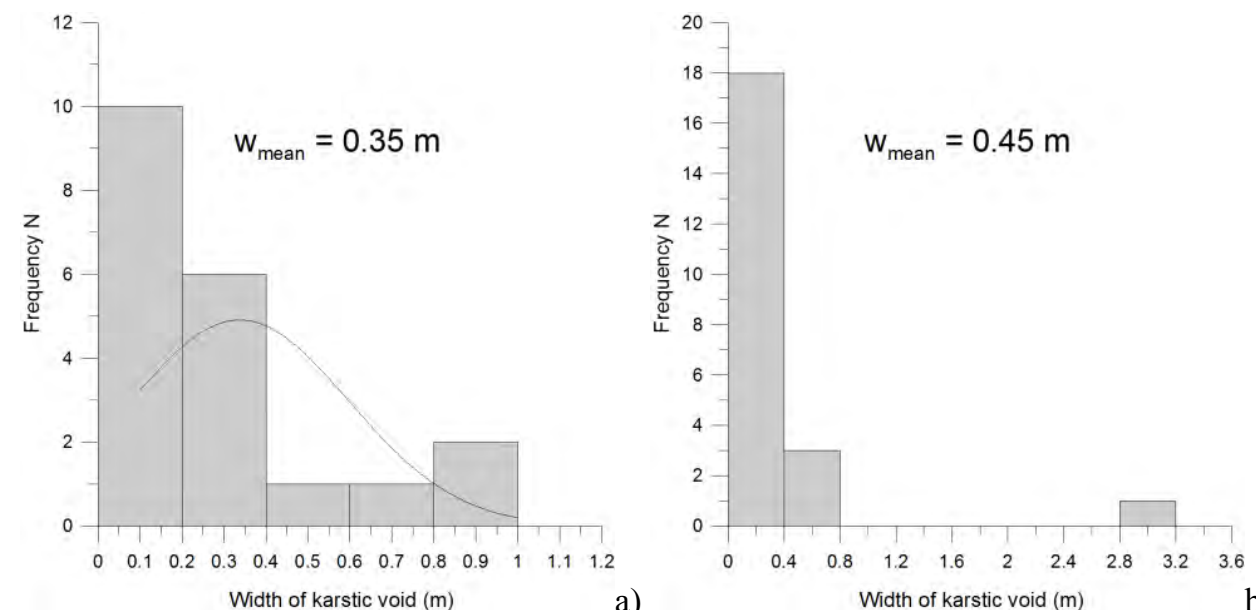

Figure 3 - Histogram of width of karstic voids encountered in a) highly cemented scree and b) Cretaceous limestone.

$\underline{\text { XLVII. No } 3-1875}$ 


\subsection{Fault Zone Geometry}

The geometry of the major fault lines was determined by photogeological interpretation of the aerial photographs of the area. The major fault zones intersecting the existing highway are presented in Figure 4a. In order to determine the predominant directions of the major faults that intersect the area of Klokova, a rose diagram was prepared based on the data collected during the geological mapping, as shown in Figure 4b.

The following major fault systems were determined:

- $\quad 1^{\text {st }}$ system B060 $\left(\right.$ angle $86^{\circ}$ )

- $\quad 2^{\text {nd }}$ system B $120^{0}$ (angle $83^{0}$ )

- $\quad 3^{\text {rd }}$ system B90-100 $\left(\right.$ angle $77^{0}$ )

- $\quad 4^{\text {th }}$ system B $170^{0}$ (angle $72^{0}$ )
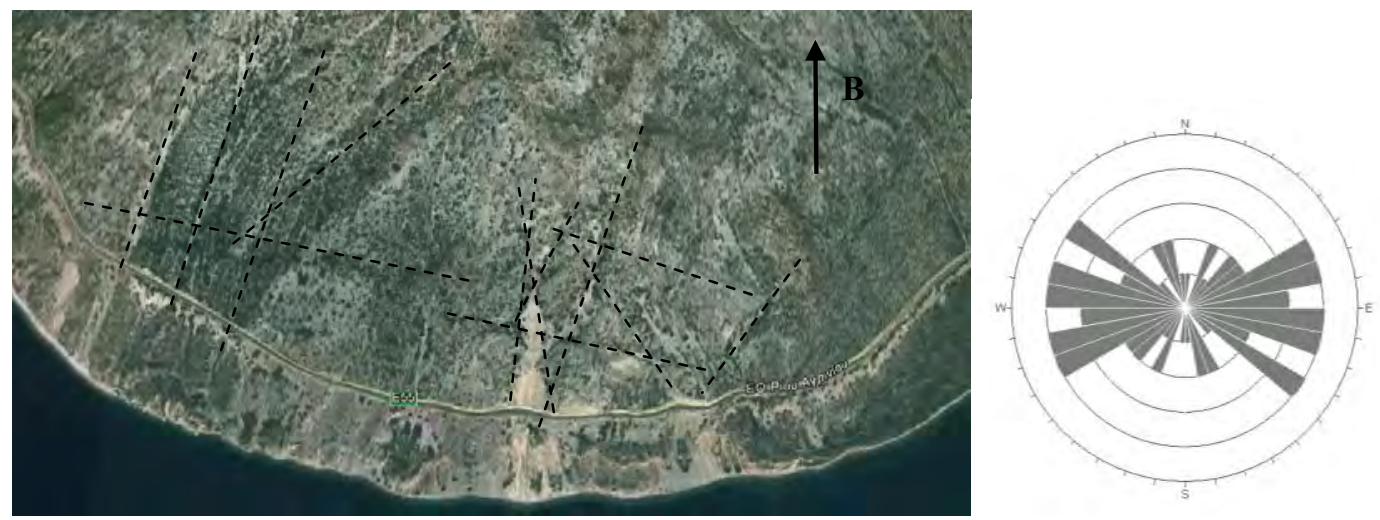

Figure 4 a) Major fault structures of Klokova area b) Orientation diagram.

\subsection{Fault zone characteristics}

The fault zones, which were recorded in the limestone rockmass along the existing road, were distinguished in two types:

- Tectonised zones in which the degree of fracturing of the limestone is high. The tectonised zones have a width in the range of a few meters (between 1 and $5 \mathrm{~m}$ ). In few locations these are found with greater width up to $15 \mathrm{~m}$ resulting in highly broken rockmass with relatively good interlocking of rock pieces.

- Zones, which are, delineated as tectonic lines and characterised by the presence of a single fault plane. In this case, the rockmass conditions adjacent to the fault plane are not influenced. These fault zones are generally open and empty.

The fault zones are characterized by the presence of secondary filling material in few cases, highly cemented which consists of gravels and irregular limestone fragments with small sizes. Generally, few of these zones were found on the surface while these were encountered in the boreholes. Their width was in the range between 2 and $5 \mathrm{~m}$.

The fault zones encountered in the boreholes were distinguished in three categories, confirming the findings of the geological mapping:

- Zones of highly broken limestone, which have a width between 1 and $5 \mathrm{~m}$. The resulting rockmass has good interlocking.

- Major fault lines, which are seen as voids in the boreholes (due to core loss) reflecting the opening along the fault plane. On either side of the zone, either mylonite material with small thickness or an abrupt transition to the fresh or slightly fractured limestone mass was recorded.

$\underline{\text { XLVII, No } 3-1876}$ 


\section{Rockmass Conditions}

\subsection{Mechanical Properties of Geological Formations}

The mechanical properties of the scree and limestone formations were evaluated based on the uniaxial compressive strength tests.

The compressive strength of the scree varies significantly in relation to the degree of cementation. The range of the uniaxial compressive strength of the cemented scree and the limestone formation is presented in Figure 5. The mean uniaxial compressive strength, $\sigma_{\mathrm{ci}}$, of loose to moderate and high cemented scree is equal to $13.2 \mathrm{MPa}$ and $22.2 \mathrm{MPa}$ respectively. The uniaxial compressive strength of limestone is equal to $55.1 \mathrm{MPa}$.
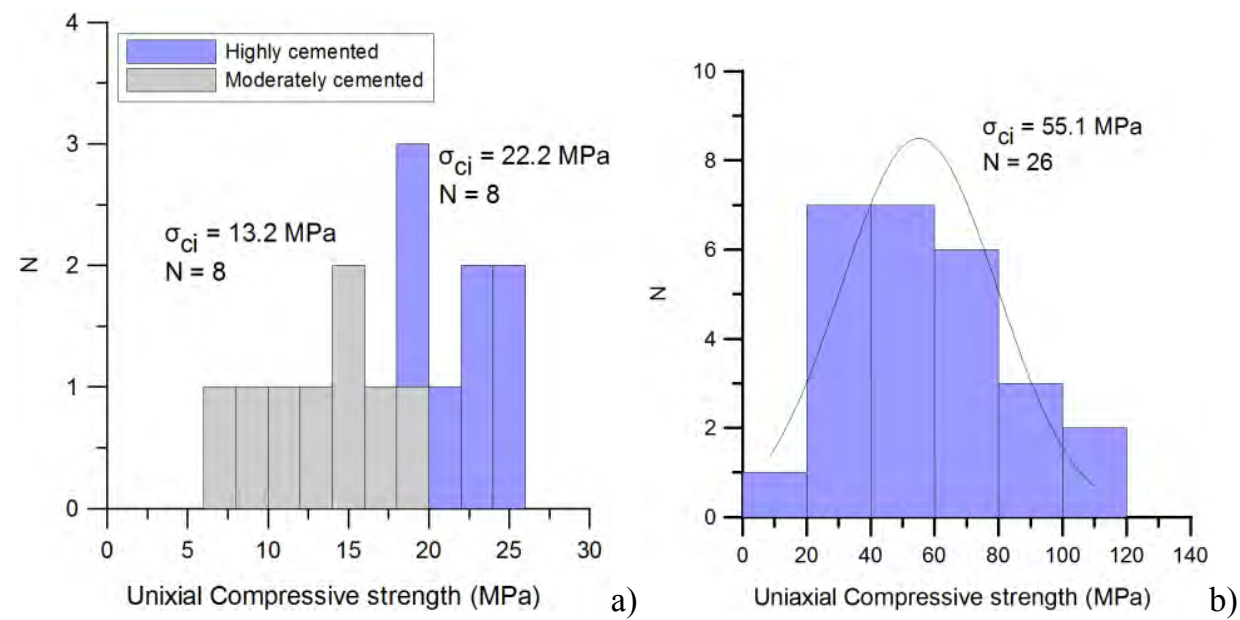

Figure 5 - Histogram of uniaxial compressive strength of a) loose to moderately and highly cemented scree and b) Cretaceous limestone.

\subsection{Rock Mass Classification}

In order determine the rockmass conditions of the limestones encountered at the surface and in the boreholes, a classification according to RMR (Bieniawski, 1976) and GSI (Marinos \& Hoek, 2000) was performed for the total length of the borehole cores (392 m approximately). A typical view of these rockmass types in boreholes as well as the range of GSI values is shown in Figure 6. Three main rock types were distinguished:

- Blocky rockmass type, which locally presents parts of practically intact rock (in which the distance of discontinuities is greater than $2 \mathrm{~m}$ ), with good to fair joint surface conditions (Figure $6 \mathrm{a}$ and $\mathrm{b}$ ). This rockmass type is rated in the range $\mathrm{RMR}=70-85$ and $\mathrm{GSI}=65-80$.

- Very blocky rockmass type, which generally entails parts of better quality rockmass (blocky) with fair to good joint surface conditions (Figure 6c). This rockmass type is rated in the range $\mathrm{RMR}=50-65$ and $\mathrm{GSI}=40-60$. It can be seen, that the very blocky rockmass type includes sections with lower degree of fracturing resulting in a blocky rockmass.

- Disintegrated rockmass type due to the tectonic disturbance in fault zones. The width of these zones is generally small, up to $2-5 \mathrm{~m}$ (Figure 6d). This rockmass type is rated in the range $\mathrm{RMR}=35-45$ and $\mathrm{GSI}=25-35$.

The rockmass categories, as encountered in the boreholes in Klokova area, were the following: Category 1: RMR $>65$ and GSI $>65$ (presence at a percentage of 43.9\%), Category 2: $45<$ RMR $<65$ and $35<\mathrm{GSI}<65$ (presence at a percentage of 52.8\%), Category 3: RMR $<45$ and GSI $<35$ (presence at a percentage of $3.3 \%$ ). The range of GSI of each rockmass category in respect to the borehole core length is presented in Figure 6e. 

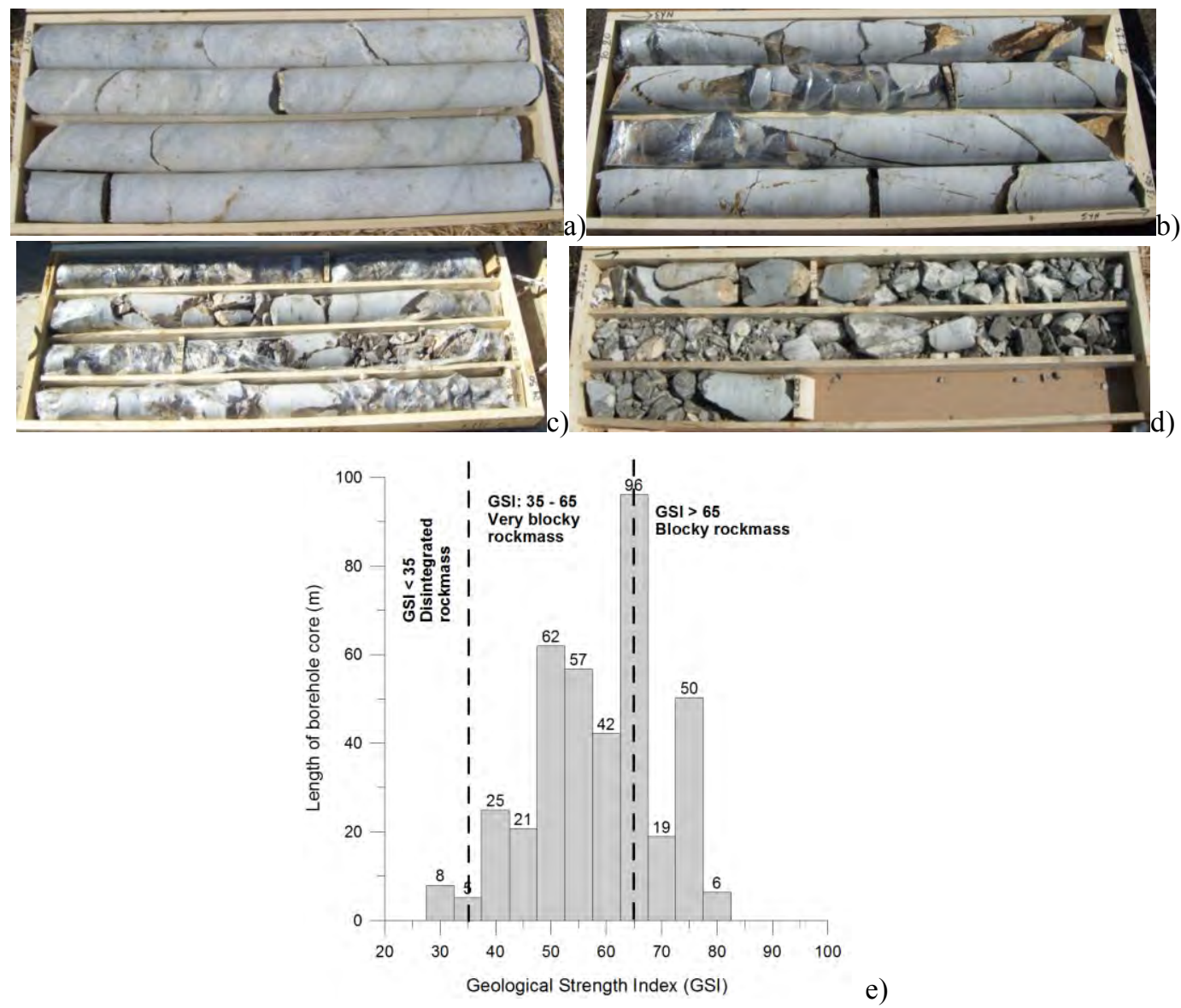

e)

Figure 6 - a) to d) Rockmass types e) range of GSI for each rockmass category of limestones

\section{Rockfall Risk}

\subsection{General}

The rockfall risk of Klokova area is very high due to the overhanging steep rocks slopes adjacent to the existing roadway and the high seismic activity of the broader area. The areas with high rockfall hazard are the following:

- Sections where fault surfaces form very steep (almost vertical) or overhanging rock slopes adjacent to the roadway as shown in Figure 7a. Single rock blocks can be found at the crest or on distinct locations on these slopes.

- Sections where the rock cliffs at higher elevations create potential conditions for detachments of large rock quantities, which although part of the rockfall trajectory may be on slope talus the falling blocks may eventually reach the roadway with substantial impact energies.

- Sections where the rockmass is highly fractured and the slopes are adjacent to the roadway, usually found at moderate slope heights. The risk becomes higher if the slope height is higher (Figure $7 \mathrm{~b}$ ). Such cases are encountered in tectonised zones in which the degree of fracturing of the limestone is high.

The detachment of rocks may occur due to seismic loading or by the action of water percolating through the limestone rockmass. The phenomenon may be triggered also due to the loss of support 
of blocks where open discontinuities and karstic voids exist. Low or medium risk areas are those in sections with relatively small heights of slopes. Considering the proximity of the high rock slopes (height up to $100 \mathrm{~m}$ ) to the roadway and the magnitude of impact of a potential rockfall episode, it could be considered that the existing retaining structures offer little protection. The existing mitigation measures include two retaining walls with low energy barriers on their crest, located in the middle section of Klokova area (Figure 7a and b) as well as wire rope nets installed on rock slopes with relatively small height and in restricted length.

\subsection{Rockfall Analysis}

A rockfall analysis was performed in two sections of the roadway, at Chainage $7+730$ and $7+850$, which have different characteristics both in slope geometry and geological materials on the slope. In Section $7+730$, scree is found in the lower part of the slope with an inclination of $35^{\circ}$ and limestone in the upper part of the slope. In Section $7+850$, the limestone slope has an inclination of $85^{\circ}$ overhanging the road.

The height of the potential rockfall source is 115 and 85 metres respectively above the road level. Their locations were defined during geological mapping. The size of the unstable blocks, which are more probable to fall, is between $1 \mathrm{~m}^{3}$ and $4 \mathrm{~m}^{3}$. The size of the falling block in the analysis was considered equal to $2 \mathrm{~m}^{3}$. In order to model the trajectory of the falling rocks and calculate the impacting kinetic energy, it is necessary to estimate accurately the normal and tangential coefficients of restitution $\left(\mathrm{R}_{\mathrm{n}}\right.$ and $\left.\mathrm{R}_{\mathrm{t}}\right)$ of the scree and limestone. The coefficients of normal and tangential restitution for the scree and limestone were considered equal to $R_{n}=0.35$ and 0.45 and $\mathrm{R}_{\mathrm{t}}=0.55$ and 0.80 respectively (Saroglou et. al, 2010). The initial velocity of the falls was taken equal to $0.48 \mathrm{~m} / \mathrm{s}$ due to seismic triggering (based on the acceleration coefficient of the area according to the Greek Earthquake Resistant Regulations, 2004). The analysis was performed using the software RocFall of Rocscience Inc (1998).

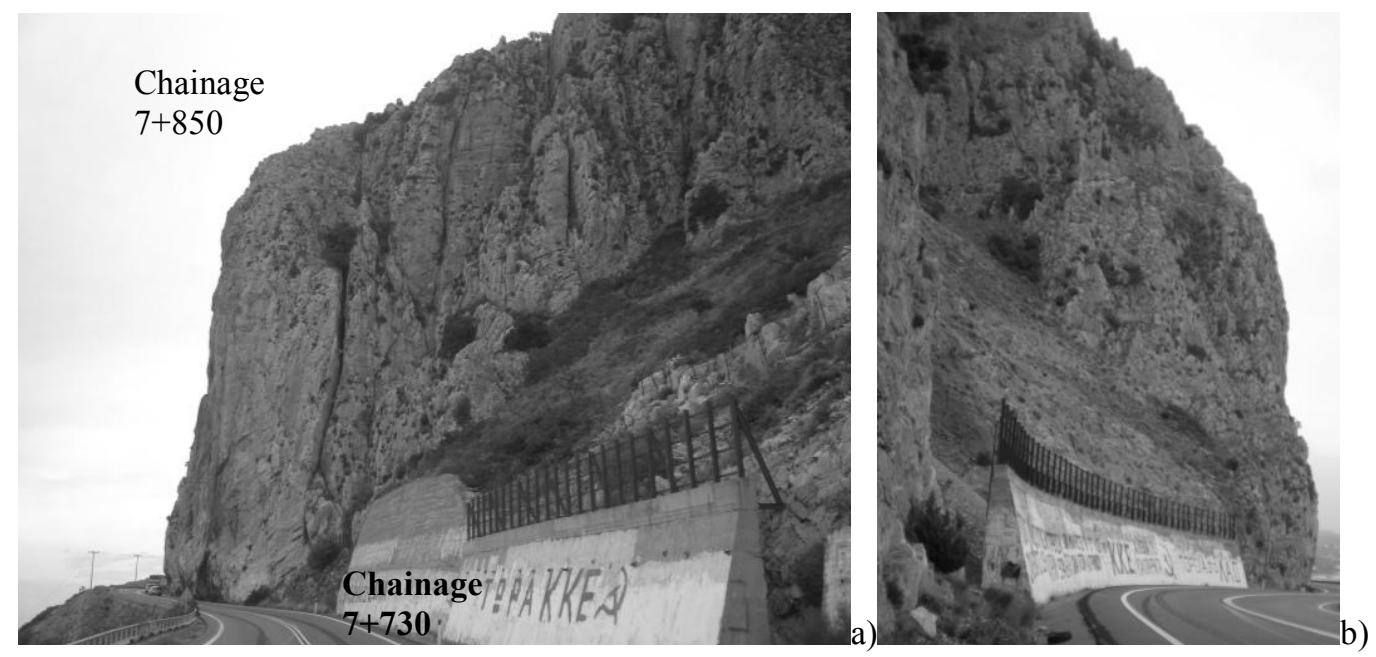

Figure 7 - Very steep slope morphology (overhanging slopes) posing a very high rock fall risk.

The maximum kinetic energy on the roadway in Chainage $7+730$ was $1100 \mathrm{~kJ}$ while in Chainage $7+850$ it reached $3500 \mathrm{~kJ}$. The presence of scree on the slope and its lower inclination in section $7+730$ resulted in lower total kinetic energy and bounce height.

An example of the analysis in Chainage $7+850$ is shown in Figure 8, depicting the trajectories of rocks and the total kinetic energy distribution at the road level. Based on the results of the analyses, it can be concluded that the nature of the geological formation on the slope as well as the slope geometry, is decisive on the magnitude of the total kinetic energy at impact on the road. It can also

$\underline{\text { XLVII, No } 3-1879}$ 
be concluded that rockfall barriers should be installed on the slope face in order to restrain the falling rock before the falling rock reaches the road. The installation of barriers in locations with adequate catchment area can be effective, while in locations with no or very limited catchment area, the construction of rockfall galleries may be necessary.

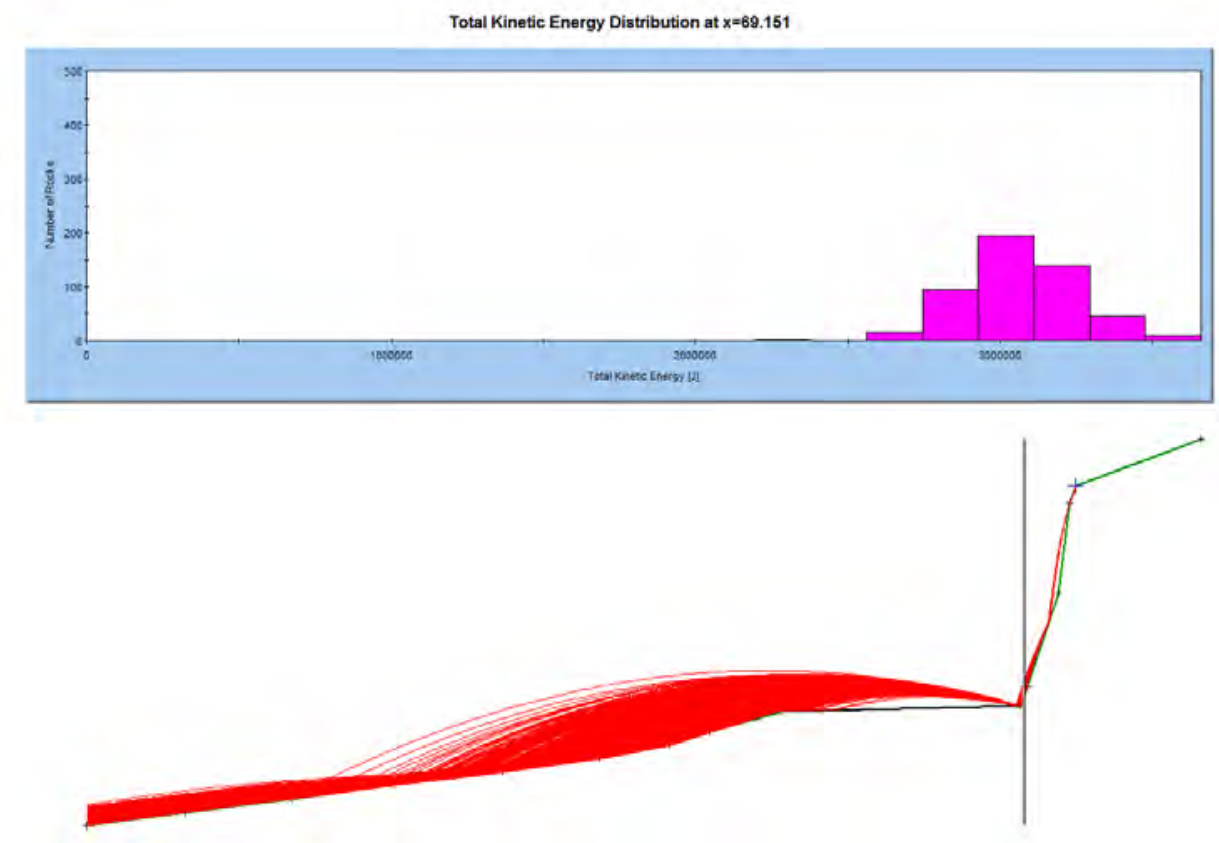

Figure 8 - Rockfall analysis at chainage $7+850$.

\section{Conclusions}

In the present paper, the engineering geological conditions of Klokova area were determined and analyzed based on geological mapping and evaluation of geotechnical investigations. These are characterized by the existence of a unique tectonic regime due to the neo-tectonic activity of the broader area, the development of a karstic network in the carbonate rocks (cemented scree and limestone) as well as the formation of very high steep rock slopes parallel to fault surfaces. The karstic network was described taking into account the conditions of fracturing due to faults. The network is developed in the cemented scree formation and limestones mainly parallel to bedding surfaces and along faults in the form of fracture karst and gullies.

The quality of the limestone rockmass is determined by the frequency of fracturing and the possible presence of karstic voids. Three main rockmass types were evaluated in the limestone formation according to GSI classification defined by distinct degree of fracturing and discontinuity surface conditions, ranging between disintegrated, very blocky and blocky to massive categories.

Finally, the rockfall conditions were analyzed for the study area by selecting two different sections with similar total slope height but with different slope geometry and geological materials on the slopes. It was concluded that the nature of the geological formation on the slope, either scree or limestone, as well as the slope geometry, was very decisive on the magnitude of the total kinetic energy at impact on the road.

\section{References}

Aubouin J., Brunn J.H. and Celet P., 1958. Les massifs du Klokova et Varassova (Akarnanie), Annales Geologiques de Pays Helleniques, Geological Society of Greece, 9, 256-59.

$\underline{\text { XLVII, No } 3-1880}$ 
Bieniawski Z.T., 1976. Rock mass classification in rock engineering, in: Bieniawski ZT (eds) Exploration for rock engineering, vol 1. Balkema, Cape Town, 97-106.

Nama S.A., - Kastor Ltd., 2005. Geotechnical investigation for the project of Klokova from Chainage 7+379-8+622.84 in the frame of studies for the section Antirio - Kefalovriso of the West Highway Axis N-S - Ionia Highway.

General Consulting Ltd - Istria, 2007. Geotechnical report and evaluation from chainage 9+300 to $10+200$.

Greek Earthquake Resistant Regulations 2004. Earthquake Planning and Protection Organisation.

Geodata Greece, 2009. Geological - geotechnical evaluation report of Klokova Tunnel.

Marinos P. 2005. Experiences in tunneling through karstic rocks. Water resources \& environmental problems in Karst, KARST 2005, IAH Inter. Conf. Proceedings, Belgrade, 617-644.

Marinos P., Hoek E. 2000. GSI: a geologically friendly tool for rock mass strength estimation. Proceedings of the GeoEng2000, International conference on geotechnical and geological engineering, Australia, Melbourne, Technomic Publishers, Lancaster, 1422-1446.

Saroglou H., Mpekri E., Tsiambaos G. 2010. Determination of critical geotechnical parameters of geological formations for the modeling of rockfalls in slopes. Proc. $6^{\text {th }}$ Hellenic Conf. of Geotechnical and Geoenvironmental Engineering, Volos, 2, 43-50. 